\title{
Milk protein based edible films and coatings- preparation, properties and food applications
}

\begin{abstract}
The interest in the study of edible film development and functions had recently become apparent in several research institutes. The dynamic forces behind this keen chase includes scientific innovation in the functionality of new materials, increased demand for novel foods and increased consciousness for environmental protection and conservation. Milk proteins are used to produce edible coatings as they impart moderate elongation, good tensile strength, act as good oxygen barriers, retard moisture loss and are flexible and generally have no taste or flavour. Developments of milk proteins based edible films are the constant attempts to offer value-added uses to milk constituents.
\end{abstract}

Keywords: milk protein, edible film, coatings, moisture barrier, gas barrier, aroma barrier, antimicrobial, neutraceutical

\author{
Volume 8 Issue 2 - 2018
}

\author{
Shendurse AM,' Gopikrishna G, ${ }^{2}$ Patel AC, ${ }^{2}$ \\ Pandya $\mathrm{AJ}^{3}$ \\ 'Department of Dairy Chemistry, Sardarkrushinagar Dantiwada \\ Agricultural University, India \\ ${ }^{2}$ Department of Dairy Technology, Sardarkrushinagar Dantiwada \\ Agricultural University, India \\ ${ }^{3}$ Department of Dairy Processing \& Operations, AAU, India
}

Correspondence: AM Shendurse, College of Dairy Technology, Department of Dairy Chemistry, Sardarkrushinagar Dantiwada Agricultural University, Sardarkrushinagar - 385506, Banaskantha, Gujarat, India, Email amshendurse@gmail.com

Received: January 30, 2018| Published: April 30, 2018
Abbreviations: $\mathrm{CN}$, casein; WPI, whey protein isolate; LG, lactoglobulin; BSA, bovine serum albumin; Ig, immunoglobulin; PP, proteose peptone; TMP, total milk proteins; NFDM, non-fat dry milk; UF-TMP, ultra-filtered-total milk proteins; WVP, water vapor permeability; UF, ultrafiltration; WPC, whey protein concentrate; TEG, triethylene glycol; PG, propylene glycol; WPI, whey protein isolate; HPMC, hydroxyl-propyl-methyl-cellulose; WPFs, whey protein isolate based edible films; NAE, natural antioxidant extracts; $\mathrm{SA}$, salvia officinalis; $\mathrm{RH}$, relative humidity; PABA, $p$-aminobenzoic acid; SA, sorbic acid; LPOS, lactoperoxidase system; CEO, cinnamon essential oil; PRO, propionic acid; LA, lactic acid; COS, chitooligosaccharides; NA, natamycin; WPEF, whey protein edible films; CI, cinnamon; $\mathrm{CU}$, cumin; $\mathrm{TH}$, thyme; $\mathrm{CC}$, calcium caseinate; GC, gluconal cal

\section{Introduction}

Consumer demands for better quality and safe foods are ever increasing. The expectations of 'invisibly processed foods', i.e., preprocessed foods which minimizes the efforts of cooking at home but possess the same sensory characteristics and quality as prepared by using original raw materials, is rising gradually. ${ }^{1}$ Edible coatings offer enhanced food quality, stability and safety. Edible films and coatings are prepared from edible biopolymers (viz. proteins, polysaccharides, lipids or mixture of these) and food grade additives. ${ }^{2,3}$ The eco-friendly nature of these biopolymers with excellent keeping quality and safety adds value to edible films and coatings. ${ }^{4}$ Edible films have the potential to extend shelf life and improve food quality by controlling mass transfer between the environment and food and also between various food product components. ${ }^{5}$ Edible films has great potential for improving the quality of foods by restricting the migration of moisture, $\mathrm{CO}_{2}, \mathrm{O}_{2}$, lipids, colours and flavours between food components, carrying food ingredients (e.g. antimicrobials, antioxidants, flavour) and/or improving the mechanical and rheological characteristics. ${ }^{6,7}$
The edible films are generally made from proteins, lipids and polysaccharides that are used either alone or together. ${ }^{8,9}$ Milk proteins are the excellent components for preparation of edible films and coatings. Milk proteins are more nutritious in nature as compared to many other food protein sources..$^{10}$ Milk proteins, besides their nutritional properties; impart many important physical characteristics for effective behaviour in edible films, such as their ability to act as emulsifiers and solubility in water. Although edible films and coatings are not expected to completely replace conventional packaging materials, they can be used to extend food stability and prevent surface contamination. ${ }^{11-14}$

\section{Milk proteins}

Total bovine milk proteins consist of about $80 \%$ casein and $20 \%$ whey proteins. Four principal casein components are $\alpha_{\mathrm{s} 1}, \alpha_{\mathrm{s} 2}-, \beta-$, $\kappa$-casein $(\mathrm{CN})$ and a minor component is $\gamma-\mathrm{CN}$. A representative distribution of these caseins is $38,10,36,13$ and $3 \%$, respectively. Whey proteins contains five fractions, namely, $\alpha$-latalbumin $(\alpha$ LA), $\beta$-lactoglobulin ( $\beta$-LG), Bovine Serum Albumin (BSA), Immunoglobulin (Ig) and Proteose peptone (PP); the theoretical compositional distribution is $20,52,7,12$ and $9 \%$ respectively. Whey proteins are globular and soluble at $\mathrm{pH} 4.6$. The number of cystein groups in $\alpha$-LA, $\beta$-LG, BSA and Ig is 4, 2, 17, and 32, respectively. ${ }^{15}$ Commercially produced whey protein isolate (WPI) has been studied for forming edible films.

\section{Film preparation and properties}

\section{Films from total milk proteins}

The edible films and coatings can be formed from total milk proteins (TMP) or components of milk proteins. Many studies have been carried out to understand the effect of protein structure and composition on edible film barrier properties. The biopolymer based (protein-protein) interactions are crucial for forming a continuous 3-D network in cohesive films. The extension of interactions depends 
upon the type and nature of protein and the surrounding conditions. ${ }^{16}$

Milk proteins based edible films and coatings acts as a protective layer on foods or between food components. Their important functionalities include mechanical protection, control of mass transfers and sensory properties. Sufficient mechanical strength is necessary to protect the integrity of packaging throughout distribution. Control of mass transfers involves controlling migration of ingredients and additives in the food systems, preventing dehydration of foods and regulating microenvironments of gases around foods. Also, the key factor for acceptance of an edible film or coating is their sensory appeal. Moreover, the simple milk protein films are good barriers to gas transfers because of their complex intermolecular bindings. ${ }^{17}$

The TMP obtained from non-fat dry milk (NFDM) could be used for formation of edible films. The film solution is dried at room temperature on smooth casting surfaces. The presence of lactose makes the TMP films formation process as complicated as it get crystallized during the process which results in non-homogeneous film formation and adhesion of film to surfaces. Addition of potassium sorbate inhibits crystallization. Moreover, the ultra-filtered-total milk proteins (UF-TMP) films has better moisture barrier and are more flexible, but denaturation by ethanol decreases the water solubility of film. Insoluble films are produced by heating TMP solution to $135^{\circ} \mathrm{C}$. The films thus prepared are stronger and less brittle due to dissociation of micelles and formation of intermolecular bonds..$^{18}$

Maynes \& Krochta $^{19}$ also investigated the mechanical properties and water vapor permeability of edible films made from various TMPs. They prepared two TMPs from NFDM by removing lactose and three TMPs were prepared from a commercial source. Lactose was extracted from NFDM by ultrafiltration (UF) or suspension in ethanol followed by filtration. The edible films prepared from TMP concentrate obtained by UF had the lowest water vapor permeability (WVP) and the highest tensile strength at break. Commercial TMP concentrates produced films more ductile than those from the UF $\square$ TMP or retentate from ethanol extraction.

Wagh et al. ${ }^{20}$ prepared the casein and whey protein concentrate (WPC) films through casting by plasticizing with sorbitol and glycerol independently. The type of biopolymer, plasticizer and its concentration influenced the properties of film. The thickness of film, water vapor permeability (WVP) and tensile strain were increased by increasing the concentration of plasticizer, but the tensile strength and elastic modulus were decreased.

\section{Films from caseins and caseinates}

Caseins are soluble and can form films exhibiting resistance to denaturation and/or coagulation even at high temperature, and thus the protein film remains stable over a wide range of temperature, $\mathrm{pH}$ and salt concentrations. Caseinates on other hand can easily form films from aqueous caseinates solutions due to their randomly coiled structure and their ability to form extensive intermolecular hydrogen, hydrophobic and electrostatic bonds, which results in an increase in inter chain cohesion. These films are water-soluble, but subjecting these films to buffer solution at $\mathrm{pH} 4.6$ results in water-insoluble films. ${ }^{18}$

Casein films for food packaging purpose possess low oxygen permeability and good strength, but have low flexibility and are more sensitivity to moisture. The casein-based films could be used in a variety of commercial applications by modifying the films depending on environmental conditions. Pectin may be added to the formulations of casein film intended for food packaging applications as per the utilization conditions and desired film properties. ${ }^{21}$

Chambi \& Grosso ${ }^{22}$ produce cross-linked casein, gelatin and casein-gelatin blend (100:0, 75:25, 50:50, 25:75 and 0:100) edible films by using transglutaminase. The cross-linkages of casein and gelatin films by the enzyme transglutaminase stimulated the formation of high molecular mass polymers, resulting in changes in the water vapor permeability and mechanical properties of films. In the study, casein-gelatin film showed significant greater elongation values $(\mathrm{P}<0.05)$ with or without transglutaminase treatment, as compared to films made from gelatin or casein alone. The mixture of gelatin and casein produced a synergistic effect on the film properties; the greatest effect being observed for the $(75: 25)$ casein-gelatin formulation, showing elongation values of $56.79 \%$ and $27.23 \%$ for the samples with and without enzymatic modification, respectively. A decrease in WVP from 7.17 to $5.06 \mathrm{~g} \mathrm{~mm} / \mathrm{m} 2 \mathrm{~d} \mathrm{kPa}$, was observed in the mixture after the action of enzyme.

Buschbaum et al., ${ }^{23}$ prepared casein films with the spin-coating technique of aqueous casein solutions on base-treated glass surfaces. The film structure was examined in real space with optical microscopy and atomic force microscopy in reciprocal space with grazing incidence small-angle X-ray scattering (GISAXS). The size of the substructures detected in the film increased with $\mathrm{pH}$ from $170 \mathrm{~nm}(\mathrm{pH}$ 5.1) up to $490 \mathrm{~nm}$ (pH 9.4). The average diameters of casein micelles in solution showed the same quantitative increase as revealed by dynamic light scattering experiments. This result suggests that the substructures detected in the bulk like films with GISAXS reflect intact casein micelles. The caseinate films and coatings do not possess a significant moisture barrier property due to their highly hydrophilic nature. The barrier properties of films could be effectively improved by increasing the cohesion between protein polypeptide chains. Krochta et al., ${ }^{24}$ prepared the casein-lipid emulsion films that had improved moisture barrier properties by taking advantage of the emulsifying property of casein. In those emulsion films, the lipid material provided resistance to water transfer, while the casein provided structural cohesion, bound the film to wet surfaces, and reduced the waxy appearance.

Calcium caseinate (CaCas), isolated from nonfat dry milk (NFDM), could be used for the production of protein based edible films and coatings. Serife \& Yam $^{25}$ produced edible CaCas films by incorporating high methoxyl pectin to improve its mechanical strength. Pectin acts as an additive and provides the crosslinks in the molecular structure of film as the pectin molecules have both methoxyl and carboxyl functional groups which crosslinks with amino acids of CaCas. Kozempel \& Tomasula ${ }^{26}$ developed a semicontinuous process to prepare films from calcium caseinate plasticized with glycerol. Polyethylene/Mylar belts were used to spread wetted solutions of calcium caseinate/glycerol and they were readily removed after forming films. The solutions were spread on belt by using a Meier rod. Feed rates were 3.3 and $5 \mathrm{~g} / \mathrm{cm}$. The resulting films using the polyethylene belt had a tensile strength of $5 \mathrm{MPa}$ and $30 \%$ elongation with thickness of $0.14 \mathrm{~mm}$. Kozempel et al., ${ }^{27}$ also determined the drying curves for making calcium caseinate/glycerol films at low and high relative humidity at $21-34^{\circ} \mathrm{C}$. They suggested that the optimal concentration for preparing edible films made from $\mathrm{CaCas}$ or $\mathrm{CO}_{2}-$ Cas was $10 \%(\mathrm{w} / \mathrm{w})$. 
Mezgheni et al., ${ }^{28}$ produce caseinate based sterilized edible films by using gamma-irradiation and studied the effect of calcium ions $\left(\mathrm{Ca}^{2+}\right)$ and two plasticizers, namely triethylene glycol (TEG) and propylene glycol (PG), as well as the effect of irradiation on both gel formation and mechanical properties of the resulting films. It was observed that gamma-irradiation leads to formation of bityrosine, i.e. crosslinks, resulting in the increase of puncture strength of films. Moreover, presence of TEG or PG improved the formation of crosslinks, resulting in an improved mechanical strength of films. TEG was responsible for the improved film extensibility as it interacted more favorably with the caseinate than PG. Brault et al., ${ }^{29}$ also used gamma-irradiation to prepare cross-linked calcium caseinates (CaCas) films. Their work showed that the films had improved mechanical properties and were water resistant.

\section{Films from whey proteins}

Whey proteins make excellent oxygen, aroma and oil barrier films at low-to-intermediate relative humidity. In addition, the mechanical properties of whey protein films are adequate to provide durability when used as coatings on food products, films separating layers of heterogeneous (made from different ingredients) foods, or films formed into pouches for food ingredients. Industrially produced whey protein concentrates (WPC) have a protein content of $25-80 \%$. Whey protein isolates (WPI), which have a protein content of about $90 \%$, are prepared from WPC by adding an ion-exchange step. ${ }^{30}$

The increase in awareness about environment protection has also contributed toward growth of whey proteins based edible films and coatings. Moreover, along with edible packaging material; these films serve other functions, viz. carrier of nutraceuticals, antioxidants or antimicrobials. These films do not significantly compromise the desirable primary barrier and mechanical properties as packaging films and hence add value for ultimate commercial applications. ${ }^{31}$

The globular structure of $\beta$-lactoglobulin gets denatured on heating above $65^{\circ} \mathrm{C}$. This exposes the hydrophobic and sulfhydryl groups which encourages oxidation of free sulfhydryls, hydrophobic bonding and disulphide bond interchange. Thus the water-insoluble edible films could be prepared. The interaction between caseins and whey proteins also gets supported by heat denaturation which causes dissociation of micellar proteins. Addition of plasticizer in the denatured film solution could improve material flexibility, but increases the WVP. The WPC based edible films are developed and compared with other protein products for effective functionality. ${ }^{18}$

McHugh et al., ${ }^{32}$ produced whey protein isolate films without using enzymes by heating $8-12 \%$ whey protein solution between 75 and $100^{\circ} \mathrm{C}$. Films were temperature. The films prepared without heat denaturation, cracked upon drying, whereas films prepared by thermal denaturation were very brittle, that demands the addition of food grade plasticizers in order to provide flexibility. The presence of covalent disulfide bonds makes the whey protein films water insoluble. WPI films are excellent barriers to the transport of $\mathrm{O}_{2}$ and $\mathrm{C}_{2}$ formed by drying film solution overnight on smooth, level casting surfaces at room $\mathrm{O}_{2}{ }^{33}$ Gounga et al., ${ }^{34}$ prepared edible films from whey protein isolate (WPI), and characterized in order to select a best combination of protein concentration and glycerol (Gly) ratio. The WPI at concentrations of $5 \%, 7 \%$ and $9 \%(\mathrm{w} / \mathrm{v})$ were used at three WPI:Gly ratios $(3.6: 1 ; 3: 1$; and 2:1). The best combination of $5 \%$ WPI with a 3.6:1 WPI:Gly ratio was selected by considering two factors viz. thickness and water vapor permeability (WVP). The best results for oxygen permeability (OP) was obtained for $9 \%$ WPI with 3.6:1 WPI:Gly.

Mahmoud \& Savello ${ }^{35}$ examined the water vapour and mechanical barrier properties of $\alpha$-lactalbumin $(\alpha$-LA), $\beta$-lactoglobulin ( $\beta$-LG) and a mixture of $\alpha-\mathrm{LA}: \beta-\mathrm{LG}$ films. Transglutaminase was used as a crosslinking agent to produce films. The $5 \%$ whey proteins were covalently polymerized in a buffer solution of $\mathrm{pH} 7.5$ under reducing conditions with glycerol and calcium ions. Glycerol concentration directly affected film resistance to breakage, moisture content and resistance to water vapour transfer. $\alpha$-LA: $\beta-\mathrm{LG}$ mixed films was more permeable to water vapour than either pure protein fraction.

Wang et al., ${ }^{36}$ successfully prepared a protein packaging film using whey protein concentrate (WPC) as raw material. The results showed that increasing the protein concentration lead to decreasing barrier properties of WPC film but improving its mechanical properties. Though barrier properties of WPC film lost to some extent owing to addition of glycerol, its extensibility was greatly improved. When heating temperature was $80 \square$, the barrier properties and tensile strength of WPC film was improved. Response surface analyses indicated that WPC film had optimal packaging performance at WPC concentration (10.2\%), heating temperature ( $82 \square)$ and glycerol concentration $(2.7 \%)$.

Javanmard ${ }^{37}$ produced whey protein concentrate (WPC) films through emulsification by incorporating poly-ethylenglycol (PEG), glycerol, and olive oil. Films were prepared by dispersing 10\% WPC in tap water and plasticized with different levels of glycerol, PEG or olive oil. Study revealed that increasing the levels of glycerol or PEG in the films resulted in decrease in modulus and tensile strength. Increasing glycerol content of the films at oil/protein ratios of 0.2 and 0.4 led to slight increases in elongation. The results suggested that a whey protein based edible films is a viable alternative packaging process for food and improvement of shelf life.

\section{Food applications}

Milk proteins have received attention in the edible films and coatings area because they provide the potential to control transfer of oil, oxygen, moisture, aroma and flavour compounds in food system depending on the nature of edible-film forming materials. Table 1 represents an overview about the food applications of milk protein based edible films and coatings. ${ }^{38}$

\section{Moisture barrier applications}

\section{Fresh fruit and vegetables}

Use of edible coating to minimize the deleterious effects of minimal processing has been reported for several commodities. They can provide partial barriers to moisture and gas exchange $\left(\mathrm{CO}_{2}\right.$ and $\left.\mathrm{O}_{2}\right)$ and could lead to the reduction in the spoilage of the fruits and vegetables. Quintavalla $\& V i c i n i{ }^{39}$ stated that meat, fruits, and vegetables could be protected from pathogenic microbial contamination by the use of edible films. Other functions include the barrier to fats and oils, oxygen and other gases, moisture. These barriers can be applied to ready-to eat food and fresh produce such as fruits and vegetables. ${ }^{40}$ The extent of the barrier is influenced by the chemical properties of the material used. ${ }^{41}$ The ability of films and coatings to function as barriers to water vapor relies on external conditions, which include (1) relative humidity and temperature, (2) characteristics of commodity such as maturity, variety, water activity 
and type of product, (3) characteristics of film such as viscosity, composition, chemical structure, concentration of solids, degree of

Table I Food applications of milk protein based edible films and coatings

\begin{tabular}{|c|c|c|}
\hline Milk proteins used in edible film formation & Function performed & Food application \\
\hline Casein-acetylated monoglyceride & Reduce moisture loss & Frozen fish \\
\hline Casein-stearic acid & Moisture retention & Peeled carrots \\
\hline Caseinate-acetylated monoglyceride & Moisture barrier & Celery sticks \\
\hline Sodium caseinate & Reduce water loss & Cherries \\
\hline \multirow[t]{4}{*}{ Calcium caseinate } & Prevent oxidative browning & Potato slices \\
\hline & Reduce moisture loss & Cut carrots \\
\hline & Reduce browning & Cut potatoes \\
\hline & Reduce oil migration & Peanut \\
\hline Potassium caseinate-rennet casein & Improve sensorial properties & Frozen fish fillets \\
\hline \multirow[t]{9}{*}{ Whey protein isolates (WPI) } & Reduce respiration & Apples \\
\hline & Reduce weight loss & Asparagus \\
\hline & Reduce rehydration & Strawberry pieces \\
\hline & Reduce rancidity & $\begin{array}{l}\text { Roasted peanuts \& } \\
\text { Walnuts }\end{array}$ \\
\hline & Moisture barrier & Breakfast cereal, raisins \\
\hline & Microencapsulation & Milk fat \\
\hline & Aroma barrier & Flavour (d-limonene) \\
\hline & Reduce fat uptake during frying & Pastry mix \\
\hline & Reduce mechanical loss & Dried chicken dice \\
\hline $\begin{array}{l}\text { Whey protein isolates - acetylated } \\
\text { monoglyceride (WPI-AM) }\end{array}$ & $\begin{array}{l}\text { Reduce rancidity \& Reduce } \\
\text { moisture loss }\end{array}$ & Frozen salmon \\
\hline \multirow{2}{*}{$\begin{array}{l}\text { Whey protein concentrates- Bee wax (WPC- } \\
\text { BW) }\end{array}$} & $\begin{array}{l}\text { Reduce browning \& Reduce } \\
\text { weight loss }\end{array}$ & Cut persimmons \\
\hline & Reduce enzymatic browning & Cut apple slices \\
\hline
\end{tabular}

Krochta et al., ${ }^{24}$ suggested that milk protein based edible coatings prepared with vegetable oil derivates significantly decreased the oxidative browning and moisture loss in apple slices. Avena-Bustillos et al., ${ }^{43}$ reported improved storage stability and reduced water loss of peeled carrots by using emulsion coatings of sodium caseinates (NaCas) and steric acid. Brault et al., ${ }^{29}$ reported that cross linked caseinate films, produced by $\gamma$-irradiation, had significantly reduced the water loss for strawberries during the storage and have delayed the browning of potatoes and apples.

Whey protein has been studied extensively as a coating for different foods, including intact and minimally-processed fruits and vegetables. Whey protein based coatings are more effective in reducing enzymatic browning of Golden Delicious apple slices than hydroxyl-propyl-methyl-cellulose (HPMC) based coatings due to the antioxidant effect of amino acids, such as cysteine and/or higher oxygen barrier imparted by the protein. No differences in browning were found between WPC and WPI based films. Inclusion of lipid also affected degree of browning, but these differences were not as much apparent at the end of storage, as judged by a sensory panel.
Results suggested that the shelf life of fresh-cut apples could be significantly extended by addition of anti-browning agents to whey protein coatings, combined with proper storage conditions. ${ }^{44}$

\section{Frozen foods}

Many types of coating materials have been tested in attempts to maintain quality of frozen foods, such as carrageenans, ice glazing, acetylated monoglycerides and alginates. Such coatings had limited success and acceptance. A reduced moisture loss was observed in frozen salmon pieces (stored at $-10^{\circ} \mathrm{C}$ ) as compared to uncoated salmon by the use of emulsion coatings of casein and acetylated monoglycerides. ${ }^{45}$ Stuchell \& Krochta ${ }^{46}$ demonstrated an efficient protection of salmon against lipid oxidation and water loss by a coating of a mixture of WPI and acetylated monoglycerides.

Tolga et al., ${ }^{47}$ assessed the effectiveness of whey protein isolate based edible films (WPFs) incorporated with natural antioxidant extracts (NAE) from laurel (LA, Laurus nobilis L.) or sage (SA, Salvia officinalis.) on the oxidative stability of cooked meatballs during frozen storage at $-18^{\circ} \mathrm{C}$ for 60 days. TBA values of the meatballs 
with NAE-WPF were lower than the TBA values of the meatballs with WPF and the control (C) group of samples. They suggested that the application of an antioxidant active packaging with LA or SA to meatballs is a feasible and effective antioxidant strategy for retarding oxidative changes in cooked and subsequently frozen comminuted meat products.

\section{Gas barrier applications}

\section{Fresh fruit and vegetables}

Fresh fruits and vegetables are highly perishable and approximately $50 \%$ fresh produce are deteriorated during harvest, handling, transportation and storage. Edible coatings play a very important role to handle this situation. Edible coatings are applied on whole and fresh-cut fruits and vegetables. ${ }^{48}$ The shelf life of fruits and vegetables is enhanced by reduction in solute migration through moisture loss and reduced gas exchange. Edible coatings have high potential to control discolor activity, browning, microbial activity, off flavor of fruits and vegetables and to extend their shelf life. ${ }^{49}$

Protein based edible coatings has good $\mathrm{O}_{2}$ barrier property at low relative humidity. The reason of its excellent barrier property for oxygen is its tightly packed hydrogen bonded structure..$^{50}$ Casein based edible coatings are attractive for food applications due to their exceptional sensory properties, good nutritional quality and strong potential for providing protection against surrounding environment to the food products. ${ }^{51}$ Casein is amphipathic in nature and is commonly used in emulsion preparations. Casein based edible films and coatings are easy to form because of their open secondary structure..$^{52} \mathrm{McHugh}$ \& Krochta ${ }^{53}$ observed that milk proteins acts as excellent gas barriers at low to moderate relative humidity $(\mathrm{RH})$. The $\mathrm{O}_{2}$ permeability of WPI film also showed an exponential effect on RH. Hence, WPI-based edible films and coatings have potential to provide protection against $\mathrm{O}_{2}$ in a food system when stored at intermediate or low RH. Another study indicated that WPI coatings are superior gas barriers, but they are influenced by the RH of the environment and affects resistance to permeation of oxygen and carbon dioxide. As $\mathrm{RH}$ is decreased, it increases resistance of the coating to gas transfer. At low RH, oxygen decreased and carbon dioxide increased in coated fruits. At RH values ranging from 70 to $80 \%$, anaerobic metabolism was induced due to low oxygen levels. ${ }^{54}$

It is observed that milk protein coatings are able to counteract oxidative degradation of cut fruits and vegetables through polyphenol oxidase inhibition. ${ }^{55}$ Le Tien et al. ${ }^{56}$ applied coatings of calcium caseinate and whey protein solutions on the apple and potato slices and reported that the 2 coatings efficiently delayed browning in both products by acting as oxygen barriers.

\section{Appetizers}

Peanuts cause rancidity during storage as they are susceptible to lipid oxidation that depends on oxygen concentration. Mate \& Krochta ${ }^{57}$ coated peanuts by dipping them into an increased viscosity WPI solution followed by air-drying. They observed that WPI-based edible coatings acts as an excellent barriers to oxygen on the nut surface and significantly delayed the oxygen uptake of dry-roasted peanuts at intermediate (53\%) and low $(21 \%) \mathrm{RH}$ during storage.

\section{Frozen foods}

A delayed oxidation of lipid and reduced peroxide values were observed in stored frozen king salmon by application of spraying WPI solution followed by an antioxidant spray. ${ }^{46}$ Moreover, spraying the WPI solution alone or along with WPI-acetylated monoglycerides emulsion, it showed no effect on peroxide values or moisture loss. ${ }^{58}$

\section{Aroma barrier applications}

Edible films can be used as a barrier to aroma loss as well as flavour carriers. The deterioration of flavour quality includes the loss of characteristic flavor due to oxidation or poor oxygen barrier properties. Therefore, edible films can help in retaining the characteristic flavour of food through their aroma barrier properties and also restricts the deterioration of quality of food due to oxidation by their oxygen barrier properties. The ability of edible coatings was studied by applying it to harvested fruit to prevent the loss of characteristic flavor. The use of edible coatings on citrus fruit resulted in an increase in desirable flavor compounds after storage, as compared with uncoated fruits. ${ }^{59}$

The flavour profile of the food could be improved by delayed release of flavour and aroma due to the sorption ability of edible coatings. The aroma and flavour enhancers as well as nutritional substances could be integrated by using milk protein-based edible films. Films obtained from irradiated calcium caseinates (CaCas) solutions might be used as microencapsulating agents of flavours in coating of fruits, vegetables and cheese as well as in food packaging. ${ }^{29}$

A study was carried out for developing a casein bio-degradable film, as tubular or planar films. These films were advantageous due to their biodegradability and great strength, and hence presented an excellent ability for packaging aromatic dry powders like spices, coffee and tea. ${ }^{60}$

\section{Antimicrobial applications}

The use of milk-protein-based films and coatings to carry antimicrobial agents to a variety of microbial media or food surfaces has been studied. It had also been revealed that they have the ability to carry and release antimicrobials such as potassium sorbate (K sorbate), natamycin, $p$-aminobenzoic acid (PABA), sorbic acid (SA), sodium lactate (Na lactate), e-polylysine (e-PL), nisin, lysozyme, lactoperoxidase system (LPOS) and essential oils. ${ }^{38}$

The antimicrobial activity of whey protein-based films was evaluated by incorporation of oregano essential oil and it was observed that the films containing $1.5 \%$ oregano oil had higher antimicrobial activity and the zone of inhibition ranged from 0 to $1.7 \mathrm{~cm} .{ }^{61}$ Bahram et al., ${ }^{62}$ observed the antimicrobial effects for whey protein concentrate (WPC) based edible film prepared by incorporating cinnamon essential oil (CEO) at a level of 0.8 and $1.5 \%$ v/v. Films containing CEO demonstrated appreciable antibacterial activity against both gram-positive and gram-negative strains, and exhibited good inhibitory action on the fungi. Similarly, Ramos et al., ${ }^{63}$ studied the efficacy of edible films produced from whey protein isolate (WPI) and glycerol, including incorporation of propionic acid (PRO) and lactic acid (LA), chitooligosaccharides with nominal MW of $3 \mathrm{kDa}$ (COS) and natamycin (NA) as antimicrobial agents. They reported that the films formulated with PRO, LA or COS exhibit antimicrobial activity against all microorganisms tested. LA was the most active against Gram-positive bacteria whereas, COS was the most active against Gram-negative ones. NA displayed the strongest effect against yeasts but was not active against bacteria. Manab et al., ${ }^{64}$ studied the antimicrobial activity of whey protein based edible film prepared by incorporating four organic acids i.e. acetic, lactic, propionic 
and benzoic acids (5\% v/v each). The antimicrobial activity was tested using Lactobacillus bulgaricus, Streptococcus thermophilus, Eschericia coli and Salmonella sp. They observed highest inhibition zone for $E$. coli tested sample $(11.6 \mathrm{~mm})$, whereas the lowest was reported for the Salmonella sp tested sample $(9.77 \mathrm{~mm})$. The films that contained benzoic acid showed highest inhibition zone $(11.76 \mathrm{~mm})$, and the films with lactic acid had the lowest $(10.44 \mathrm{~mm})$.

Oussallah et al., ${ }^{65}$ studied the effectiveness of milk-protein-based edible films containing $1 \%$ essential oils of oregano, pimento or an oregano-pimento mixture in a ratio 1:1 (w/w) against Pseudomonas spp. and $E$. coli $\mathrm{O} 157: \mathrm{H} 7$ on the surface of beef muscle pieces. The incorporation of essential oils into the cross-linked coating film formulation significantly decreased the microorganism level in meat samples. They also found that the most effective films against the growth of both pathogenic bacteria are those containing oregano extracts. Guilbert ${ }^{66}$ conducted microbiological tests to determine the effectiveness of sorbic acid (SA) incorporated in casein films and showed improved microbial stability. It was reported that the casein films containing SA acted as an antimicrobial agents against Staphylococcus rouxii, Aspergillus niger in the treated papaya cubes. Badr et al., ${ }^{67}$ evaluated the antimicrobial efficiency of whey protein edible films (WPEF) incorporated with $1-2.5 \%$ cinnamon (CI), cumin $(\mathrm{CU})$ and thyme $(\mathrm{TH})$ essential oils on fresh red meat during refrigerated storage at $5^{\circ} \mathrm{C}$ for 12 days. They reported the strongest inhibition on surfaces sliced meat containing TH essential oils extracts films due to its greater antimicrobial activity. In addition, significant reduction was noticed in the number of total viable bacterial count during the storage period for the WPEF that contained a high level of $\mathrm{TH}, \mathrm{CI}$ or CU essential oils.

\section{Nutraceutical application}

Milk protein based edible films and coatings also have capacity to hold many active ingredients that could be used to enhance nutritional value of food products. For such applications, the concentration of nutraceuticals added to the films or coatings must be carefully studied in relation to basic properties (e.g., barrier and mechanical) of carrier films. ${ }^{68}$ Mei \& Zha ${ }^{69}$ studied the ability of milk protein-based edible films to carry high concentrations of vitamin $\mathrm{E}$ and calcium. They used calcium caseinate (CC) and whey protein isolate (WPI) films containing 5 or $10 \%$ Gluconal Cal (GC), a mixture of calcium lactate and gluconate, or 0.1 or $0.2 \%$ of $\alpha$-tocopheryl acetate (VE), respectively. Both CC and WPI films were capable of carrying high concentrations of calcium or vitamin $\mathrm{E}$, though film functionality can be compromised in the process. The vitamin $\mathrm{E}$ incorporation at tested levels increased elongation at break and reduced tensile strength of films. Whereas, incorporation of calcium into CC films reduced tensile strength for both levels of GC addition, and decreased both elongation at break and water vapor permeability values at $10 \% \mathrm{GC}$ addition level.

\section{Conclusion}

Food processors welcome innovative technologies to meet constantly changing consumer needs. Edible coatings may inspire new product developments. The unique advantages of edible coatings may lead to new ideas such as individual packaging of particulate foods, additive carriers and nutrient supplements. When traditional dairy products have saturated the market or approach the capacity of domestic consumption, development of innovative and novel applications of milk-derived ingredients may provide the dairy industry with vital alternatives. Milk protein based films and coatings are very promising systems for the future improvement of food quality and preservation during processes and storage. They offer numerous advantages over other conventional synthetic packaging materials. Their inherent edibility and biodegradability are strong advantages of these edible films and coatings. In addition to their environmentally friendly nature, increased food safety can be achieved by incorporating active agents into the films/coatings. Edible packaging films that are more mechanically versatile and environmentally stable would better resist real processing and end-use conditions and enable a variety of new commercial applications.

\section{Acknowledgments}

Author declares no acknowledgments.

\section{Conflict of interest}

Author declares no conflict of interest.

\section{References}

1. Fabbri ADT, Crosby GA. A review of the impact of preparation and cooking on the nutritional quality of vegetables and legumes. Int $J$ Gastronomy and Food Sci. 2016;3:2-11.

2. Han JH. Edible films and coatings: a review. In book: Innovations in food packaging. 2nd ed. A volume in food science and technology. 2014;213255 .

3. Suput DZ, Lazic1 VL, Popovic SZ. Edible films and coatings-sources, properties and application. Food and Feed Res. 2015;42(1):11-22.

4. Shah U, Naqash F, Gani A. Art and science behind modified starch edible films and coatings: a review. Comprehensive Rev Food Sci Food Safety. 2016;15(3):568-580.

5. Paviath AE, Orts W. Edible Films and Coatings: Why, What, and How? In: ME Embuscado, KC Huber, editors. Edible films and coatings for food applications. Springer Science Business Media, USA; 2009:1-23.

6. Lacroix M, Vu Khanh D. Edible coatings and film materials: Proteins. In book: Jung $\mathrm{H}$ Han, editor. Innovations in food packaging. 2nd ed. A volume in food science and technology. 2014;277-304.

7. Ncama K, Magwaza LS, Mditshwa A. Plant-based edible coatings for managing postharvest quality of fresh horticultural produce: A review. Food Packaging and Shelf Life. 2018;16:157-167.

8. Nesic AR, Seslija SI. The influence of nanofillers on physical-chemical properties of polysaccharide-based film intended for food packaging. In: Alexandru Mihai Grumezescu, editor. Food Packaging. Elsevier, 125 London Wall, UK; 2017:637-697.

9. Chiralt A, Gonzalez-Martinez C Vargas. Edible films and coatings from proteins. 2nd ed. In: Rickey Y Yada, editor. Proteins in Food Processing. Woodhead Publishing Series in Food Science, Technology and Nutrition. Elsevier Ltd; 2018:477-500.

10. Bourtoom T. Edible films and coatings: characteristics and properties. Int Food Res J. 2008;15(3):237-248.

11. Janjarasskul T, Krochta JM. Edible Packaging Materials. Rev Food Sci and Tech. 2010;1(1):415-418.

12. Kapetanakou AE, Manios SG, Skandamis PN. Application of edible films and coatings in foods. In: Ioannis S Boziaris, editors. Novel Food Preservation and Microbial Assessment Techniques. CRC Press; 2014:237-273.

13. Corbo MR, Campaniello D, Speranza B. Non-Conventional Tools to 
Preserve and Prolong the Quality of Minimally-Processed Fruits and Vegetables. Coatings. 2015;5(4):931-961.

14. Otoni CG, Bustillos RJA, Azeredo HMC. Recent advances on edible films based on fruits and vegetables- a review. Comprehensive Rev Food Sci Food Safety. 2017;16(5):1151-1169.

15. Fox PF, Uniacke-Lowe T, McSweeney PLH, et al. Milk Proteins. In book: Dairy Chemistry and Biochemistry. 2nd ed. Springer, Cham; 2015:145239.

16. Phillips LG, Whitehead DM, Kinsella J. Protein films. In book: LG Phillips, DM Whitehead, J Kinsella, editors. Structure function properties of food proteins. Academic press, USA; 1994:126.

17. Chen H. Functional Properties and Applications of Edible Films Made of Milk Proteins. J Dairy Sci. 1995;78(11):2563-2583.

18. Khwaldia K, Perez C, Banon S, et al. Milk proteins for edible films and coatings. Crit Rev Food Sci Nutr. 2004;44(4):239-251.

19. Maynes JR, Krochta JM. Properties of Edible Films from Total Milk Protein. J Food Sci. 1994;59(4):909-911.

20. Wagh YR, Pushpadass HA, Emerald FME, et al. Preparation and characterization of milk protein films and their application for packaging of Cheddar cheese. J Food Sci Tech. 2014;51(12):3767-3775.

21. Bonnaillie LM, Zhang H, Akkurt S, et al. Casein films: the effects of formulation, environmental conditions and the addition of citric pectin on the structure and mechanical properties. Polymers. 2014;6(7):2018-2036.

22. Chambi H, Grosso C. Edible films produced with gelatin and casein crosslinked with transglutaminase. Food Res Int. 2006;39(4):458-466.

23. Buschbaum PM, Gebhardt R, Maurer E, et al. Thin casein films as prepared by spin-coating: influence of film thickness and of $\mathrm{pH}$. Biomacromolecules. 2006;7(6):1773-1780.

24. Krochta JM, Pavlath AE, Goodman N. Edible films from casein-lipid emulsion for lightly processed fruits and vegetables. In: WEL Spiess, $\mathrm{H}$ Schubert, editors. Engineering and Food, Preservation processes and related techniques. Elsevier Applied Sci Pub Co, London, 1990;2:329-340.

25. Serife A, Yam KL. Edible films and coatings from calcium caseinate and their applications. 2015.

26. Kozempel M, Tomasula PM. Development of a continuous process to make casein films. J Agric Food Chem. 2004;52(5):1190-1195.

27. Kozempel M, Tomasula PM, McAloon A. Drying kinetics of calcium casemate. J Agric Food Chem. 2003;51(3):773-776.

28. Mezgheni E, D’Aprano G, Lacroix M. Formation of sterilized edible films based on caseinates: effects of calcium and plasticizers. J Agric Food Chem. 1998;46(1):318-324.

29. Brault D, D’Aprano G, Lacroix M. Formation of freestanding sterilized edible films from irradiated caseinates. J Agri Food Chem. 1997;45:2964 2969.

30. DeWit JN. Lecturer's handbook on whey and whey products. 3rd ed. European Whey Products Association, Belgium; 2001.

31. Ramos OL, Fernandes JC, Silva SI, et al. Edible films and coatings from whey proteins: a review on formulation, and on mechanical and bioactive properties. Crit Rev Food Sci Nutr. 2012;52(6):533-552.

32. McHugh TH, Aujard JF, Krochta JM. Plasticized whey protein edible films: Water vapour permeability properties. J Food Sci. 1994;59(2):416-419.

33. Krochta JM. Control of mass transfer in foods with edible coatings and films. In: RP Singh, MAWirakarstakusumah, Boca Raton, editors. Advances in Food Engineering. CRC Press, Inc, FL, USA; 1992:517-538.
34. Gounga ME, Xu SY, Wang Z. Whey protein isolate-based edible films as affected by protein concentration, glycerol ratio and pullulan addition in film formation. J Food Engg. 2007;83(4):521-530.

35. Mahmoud R, Savello P. Solubility and hydrolyzability of films produced by transglutaminase catalytic crosslinking of whey protein. J Dairy Sci. 1993;76(1):29-35.

36. Wang HJ, Sun C, Huang LQ. Preparation and properties of whey protein packaging film. In: Proceedings of the 17th IAPRI World Conference on Packaging. 2010;259-264

37. Javanmard M. Biodegradable whey protein edible films as new biomaterials for food and drug packaging. Iranian J Pharmac Sci. 2009;5(3):129-134.

38. Khwaldia K. Antimicrobial films and coatings from milk proteins. In: Ra M, Chikindas M, editors. Natural antimicrobials in food safety and quality. CAB International, Wallingford, UK; 2011:114-130.

39. Quintavalla S, Vicini L. Antimicrobial food packaging in meat industry. Meat Sci. 2002;62(3):373-380.

40. Rossman JM. Commercial manufacture of edible films. In: ME Embuscado, KC Huber, editors. Edible films and coatings for food applications. Springer Science Business Media, USA; 2009:367-390.

41. Pascall MA, Lin SJ. The application of edible polymeric films and coatings in the food industry. J Food Process Technol. 2013;4(2):e116.

42. Olivas GI, Barbosa-Cánovas GV. Edible coatings for fresh cut fruits. Crit Rev Food Sci and Nutr. 2005;45(7-8):657-670.

43. Avena Bustillos RJ, Cisneros-Zevallos LA, Krochta JM, et al. Optimization of edible coatings on minimally processed carrots using response surface methodology. Trans Am Soc Agri Engg. 1993;36(3):801-805.

44. Pérez-Gago MB, Serra M, Alonso M, et al. Effect of whey protein and hydroxypropyl methylcellulose based edible composite coatings on color change of fresh-cut apples. Postharvest Biology and Technol. 2005;36(1):77-85.

45. Hirasa K. Moisture loss and lipid oxidation in frozen fish-effect of caseinacetylated monoglyceride edible coating. MS Thesis, Univ. of California, Davis; 1991.

46. Stuchell YM, Krochta JM. Edible coatings on frozen king salmon: effect of whey protein isolate and acetylated monoglycerides on moisture loss and lipid oxidation. J Food Sci. 1995;60(1):28-31.

47. Akcan T, Estevez M, Serdaroglu M. Antioxidant protection of cooked meatballs during frozen storage by whey protein edible films with phytochemicals from Laurus nobilis L. and Salvia officinalis. LWT. 2017;77:323-331.

48. Youssef ARM, Ali EAA, Emam HE. Influence of postharvest application of some edible coating on storage life and quality attributes of novel orange fruits during cold storage. Int J Chem Tech Research. 2015;8(5):21892200 .

49. Dhall RK. Advance in edible coating for fresh fruits and vegetables: a review. Critical Rev Food Sci Nutr. 2013;53(5):435-450.

50. Raghav PK, Agarwal N, Saini M. Edible coating of fruits and vegetables: a review. Int J Sci Res Modern Edu. 2016;1(1):188-204.

51. Galgano F, Condelli N, Favati F, et al. Biodegradable packaging and edible coating for fresh-cut fruits and vegetables. Ital J Food Sci. 2015;27(1):120 .

52. McHugh TH, Krochta JM. Milk protein based edible films and coatings Food Technology. 1994;48(1):97-103.

53. McHugh TH, Krochta JM. Permeability properties of edible films. In: JM 
Krochta, EA Baldwin, M Nisperos Carriedo, editors. Edible coating and films to improve food quality. Lancaster PA: Technomic Publishing Co., Inc; 1994:139-187.

54. Cisneros-Zevallos L, Krochta JM. Whey protein coatings for fresh fruits and relative humidity effects. J Food Sci. 2003;68(1):176-181.

55. Porta R, Rossi-Marquez G, Mariniello L, et al. Edible coating as packaging strategy to extend the shelf-life of fresh-cut fruits and vegetables. $J$ Biotechnol Biomater. 2013;3(4):e124.

56. Le Tien C, Vachon C, Mateescu MA, et al. Milk protein coatings prevent oxidative browning of apples and potatoes. J Food Sci. 2001;66(4):512516.

57. Mate JI, Krochta JM. Whey protein coating effect on the oxygen uptake of dry roasted peanuts. J Food Sci. 1996;61(6):1202-1206.

58. Khwaldia K, Perez C, Banon S, et al. Milk proteins for edible films and coatings. Critical Rev Food Sci Nutr. 2004;44:239-251.

59. Miller KS, Krochta JM. Oxygen and aroma barrier properties of edible films: a review. Trends in Food Sci Tech. 1997;8(7):228-237.

60. Metzger W. Method of producing casein film. US patent 5681517; 1997.

61. Oliveira SPLF, Bertan LC, De Rensis CMVB, et al. Whey protein-based films incorporated with oregano essential oil. Polimeros. 2017;27(2):158164

62. Bahram S, Rezaei M, Soltani M, et al. Whey protein concentrate edible film activated with cinnamon essential oil. J Food Process and Preserv. 2014;38(3):1251-1258.
63. Ramos OL, Silva SI, Soares JC, et al. (2012) Features and performance of edible films, obtained from whey protein isolate formulated with antimicrobial compounds. Food Res Int. 45(1):351-361.

64. Manab A, Sawitri ME, AlAwwaly KU, et al. Antimicrobial activity of whey protein based edible film incorporated with organic acids. African $J$ Food Sci. 2011;5(1):6-11.

65. Oussallah L, Caillet S, Salmieri S, et al. Antimicrobial and antioxidant effects of milk protein-based film containing essential oils for the preservation of whole beef muscle. J Agric Food Chem. 2004;52(18):5598-5605.

66. Guilbert S. Use of superficial edible layer to protect intermediate moisture foods: Application to the protection of tropical fruit dehydrated by osmosis. In: Seow CC, Teng TT, Quah CH, editors. Food Preservation by Moisture Control. Elsevier Applied Science, London; 1988:199-219.

67. Badr KR, Ahmed ZS, ElGamal MS. Evaluation of the antimicrobial action of whey protein edible films incorporated with cinnamon, cumin and thyme against spoilage flora of fresh beef. Int J Agric Res. 2014;9(5):242-250.

68. Martín-Belloso O, Rojas-Grau MA, Soliva-Fortuny R. Delivery of flavor and active ingredients using edible films and coatings. In: ME Embuscado, KC Huber, editors. Edible films and coatings for food applications. Springer Science Business Media. 2009:295-314.

69. Mei Y, Zhao Y. Barrier and mechanical properties of milk protein-based edible films incorporated with nutraceuticals. J Agric Food Chem. 2003;51(7):1914-1918. 